\title{
ANALISIS PENINGKATAN KOMPETENSI YANG BERBASIS PELATIHAN MODEL RETURN ON TRAINING INVESTMENT (ROTI) (STUDI KASUS DI PT ALPHA AUTOMOTIVE INDONESIA)
}

\author{
Ayati Hernasari \\ ayati.hernasari@gmail.com \\ NPM : 1510633405008 \\ Prodi : S2-Magister Manajemen \\ Universitas Negeri Singaperbangsa Karawang
}

\begin{abstract}
Abstrack
Increased competence with training required in PT.Alpha Automotive Indonesia has constraints in the form of trouble maker on the performance of employees. One of the efforts made by PT. Alpha Automotive Indonesia to improve employee competence is by training organized by Institutions, Companies and Industrial Estate Management. The objective of the research is to increase competence using training on return on training investment model. The method used is using qualitative research approach. Observational research techniques, interviews, documentation and Focus Group Discussion (FGD). Nature of this research is case study with single case study design (single case study). The result of the research shows that the competence based on employee training in PT. Alpha Automotive Indonesia declared managed to improve the competence of employees of PT. Alpha Automotive Indonesia by showing a good relationship between the training required by the company (training from outside) and training conducted by the company.
\end{abstract}

Keywords: Competence, Training.

116. 


\section{PENDAHULUAN}

\section{Latar Belakang Masalah}

Kondisi sekarang ini bagi perusahaan yang menjadi prasarat dalam peningkatan kompetensi untuk berkerja yang lebih optimal lagi, dengan melaksanakan program pelatihan baik internal perusahaan maupun eksternal perusahaan yang selama ini sudah berlangsung. Karena dalam hal ini kompetensi pegawai dalam suatu perusahaan adalah salah satu kunci keberhasilan bisnis, khususnya bagi perusahaan-perusahaan di industri otomotif. Pentingnya peningkatan kompetensi pegawai yang terus menerus kemudian mendorong perusahaan memberikan pendidikan dan pelatihan atau training yang memampukan pegawainya untuk menghasilkan benefit yang dihasilkan. Setelah training diberikan, tentunya perusahaan perlu mengetahui sejauhmana kontribusi training tersebut terhadap perubahan atau peningkatan kompetensi pegawai maupun perusahaan secara keseluruhan. Hal ini penting karena disadari bahwa belum tentu training yang diberikan kemudian selalu memberikan hasil yang efektif sesuai dengan yang diharapkan perusahaan. Untuk itu, perlu dilakukan evaluasi untuk mengukur sejauhmana efektivitas training tersebut terhadap tujuan yang ingin dicapai.

Hal ini menjadi acuan bagi perusahaan untuk mengetahui kemampuan kerja pegawai. Melalui kompetensi yang dimiliki oleh pegawai membantu perusahaan lebih mengetahui posisi apa yang cocok dan tepat untuk pegawai yang akan dipilihnya tersebut. Kompetensi sendiri merupakan landasan dasar karakteristik orang dan mengindikasikan cara berperilaku atau berpikir, menyamakan situasi dan mendukung untuk periode waktu yang cukup lama. Faktor yang dapat mempengaruhi kecakapan kompetensi seseorang yaitu keyakinan dan nilai-nilai, keterampilan, karakteristik pribadi, motivasi, isu emosional, kemampuan intelektual, budaya organisasi (Spancer, 2003).

Pengetahuan kompetensi sangat membantu perusahaan untuk mengetahui sejauh mana seorang pegawai dapat bekerja optimal dan memberikan kontribusi yang sesuai dengan keinginan perusahaan. Peningkatan kompetensi dengan pelatihan dibutuhkan bagi industri berkembang untuk bersaing di era perekonomian yang sedang berkembang pesat. Perusahaan berkembang di 
Indonesia membutuhkan pelatihan untuk meningkatkan kompetensi pegawai agar mampu bersaing di era globalisasi. Dengan meningkatnya kompetensi, organisasi akan mendapatkan pegawai yang lebih produktif, kreatif dan memiliki motivasi yang tinggi. Di sisi lain organisasi juga dapat melakukan efisiensi biaya dengan membuat prioritas pengeluaran dana untuk mencapai hasil yang optimal.

\section{Fokus Penelitian dan Subfokus Penelitian}

Berdasarkan latar belakang yang telah dijelaskan di atas fokus penelitian yang dilakukan di PT.Alpha Automotive Indonesia, adalah :

1. Implementasi peningkatan kompetensi sumber daya manusia yang berbasis pelatihan model return on training investment (roti)di PT Alpha Automotive Indonesia. Sub fokus dalam penelitian ini yaitu mengetahui kompetensi pegawai danfaktor-faktor untuk mengatasi hambatankompetensi dalam berbagai jenis pelatihan sebagaipencapaian rencana suksesi dan pengembangan karir pegawai untuk meningkatkan kompetensi pegawai.

2. Lokus penelitiandi pegawai staff semua departemen office PT.Alpha Automotive Indonesia.

3. Metode penelitian kualitatif, dengan unit responden : departemen HRD PT.Alpha Automotive Indonesia, departemen production control PT.Alpha Automotive Indonesia.

\section{Pertanyaan Penelitian}

Berdasarkan fokus penelitian yang telah ditetapkan tersebut, maka masalah penelitian dapat dirumuskan sebagai berikut.

1. Bagaimanakah kompetensi pada pegawai PT Alpha Automotive Indonesia?

2. Bagaimana penerapan pelatihan Model Return On Training Investment (Roti) di PT Alpha Automotive Indonesia?

3. Bagaimanakah pelatihan Model Return On Training Investment (Roti) meningkatkan kompetensi pegawaidi PT Alpha Automotive Indonesia? 


\section{Tujuan Penelitian}

Adapun tujuan penelitian yang hendak dicapai dalam penulisan proposal ini adalah:

1. Untuk mengidentifikasi kompetensi pada pegawai PT Alpha Automotive Indonesia

2. Untuk mengetahui penerapan pelatihan pegawai yang telah diberikan perusahaan dan hasil pelatihan yang diperoleh pegawaimenggunakan Model Return On Training Investment (Roti) di PT.Alpha Automotive Indonesia

3. Untuk mengkaji pelatihan Model Return On Training Investment (Roti) dapat meningkatkan kompetensi pegawai PT.Alpha Automotive Indonesia

\section{TINJAUAN TEORETIS}

\section{Manajemen Sumber Daya Manusia}

Menurut Rivai, Velthzal (2009:1) Manajemen sumber daya manusia (MSDM) merupakan salah satu bidang dari manajemen umum yang meliputi segisegi perencanaan, pengorganisasian, pelaksanaan dan pengendalian. Proses ini terdapat dalam fungsi atau bidang produksi, pemasaran, keuangan, maupun kepegawaian. Karena sumber daya manusia (SDM) dianggap semakin penting perannya dalam mencapai tujuan perusahaan, maka berbagai pengalaman dan hasil penelitian dalam bidang SDM dikumpulkan secara sistematis dalam apa yang disebut manajemen sumber daya manusia. Istilah "manajemen" mempunyai arti sebagai kumpulan pengetahuan tentang bagaimana seharusnya memanage (mengelola) sumber daya manusia.

Achmad Darodjat, Tubagus (2015:48) mengemukakan untuk menciptakan sumber daya manusia yang berkualitas dan kemampuan tinggi adalah melalui peningkatan keahliannya sebagai salah satu upaya. Menurut Gerry Dessler (2004), SDM (HRM) meliputi perekrutan dan seleksi, pelatihan dan pengembangan, kompensasi atau penghargaan dan penilaian serta hubungan tenaga kerja.

Achmad Darodjat, Tubagus (2015:49) mengemukakan fungsi manajemen sumber daya manusia sebagai berikut: 
1. Human Resource Planing. Merencanakan kebutuhan dan pemanfaatan sumber daya manusia bagi perusahaan. Untuk dapat menyesuaikan diri dengan perusahaan melalui: perencanaan sumber daya manusia.

2. Personnel Procurement. Mencari dan mendapatkan sumber daya manusia, melalui : rekrutmen, seleksi, penempatan serta kontrak tenaga kerja, induksi.

3. Personnel Depelovment. Mengembangkan sumber daya manusia, keterampilannya, keahlian dan pengetahuannya melalui: program orientasi tenaga kerja, pendidikan dan pelatihan (analisis dan evaluasi), pengembangan karir.

4. Personnel Maintenance. Memelihara sumber daya manusia, gaji, reward, insentif, jaminan kesehatan dan keselamatan tenaga kerja, menyelesaikan perselisihan perburuhan; menyelesaikan keluhan dan relationship karyawan dan lain sebagainya. Agar sumber daya manusia berdedikasi tinggi, melalui; kesejahteraan (kompensasi), lingkungan kerja yang sehat dan aman, hubungan industrial yang baik.

5. Personnel Utilization. Memanfaatkan dan mengoptimalkan sumber daya manusia, termasuk didalamnya promosi, demosi, transfer, dan juga seperasi. Agar sumber daya manusia bekerja dengan baik melalui; otivasi, penilaian karya atau feed back, peraturan

\section{Kompetensi}

Kompetensi adalah karakteristik dasar dari seseorang yang memungkinkan mereka mengeluarkan kinerja superior dalam pekerjaannya. Kompetensi menurut Spencer dan Spencer dalam Palan (2007) adalah sebagai karakteristik dasar yang dimiliki oleh seorang individu yang berhubungan secara kausal dalam memenuhi kriteria yang diperlukan dalam menduduki suatu jabatan.

Spencer and Spencer dalam Wibowo (2010:325) mengemukakan bahwa kompetensi adalah merupakan landasan dasar karakteristik orang dan mengidentifikasikan cara berperilaku atau berfikir, menyamakan situasi dan mendukung untuk periode waktu cukup lama.

Kompetensi menurut UU No. 13/2003 tentang Ketenagakerjaan: Pasal 1 (10), “Kompetensi adalah kemampuan kerja setiap individu yang mencakup aspek 
pengetahuan, keterampilan dan sikap kerja yang sesuai dengan standar yang ditetapkan".

Pertimbangan kebutuhan kompetensi mencakup:

1. Permintaan masa mendatang berkaitan dengan rencana dan tujuan strategis dan operasional organisasi

2. Mengantisipasi kebutuhan pergantian manajemen dan karyawan

3. Perubahan pada proses dan teknologi dan peralatan organisasi

4. Evaluasi kompetensi karyawan dalam melaksanakan kegiatan dan proses yang ditetapkan.

Kompetensi terdiri dari 5 tipe karakteristik yang dikutip oleh Panji (2009:33), yaitu sebagai berikut:

1. Keahlian (Skill) yaitu kemampuan untuk melaksanakan suatu tugas tertentu baik secara fisik maupun mental

2. Pengetahuan (Knowledge) yaitu suatu informasi yang dimiliki seseorang untuk bidang tertentu. Knowledge merupakan kompetensi yang kompleks

3. Sikap atau nilai (Self-Concept) yaitu sikap dan nilai-nilai yang dimiliki seseorang

4. Watak atau sifat (Trait) yaitu watak yang membuat orang untuk berprilaku atau bagaimana seseorang merspon untuk berperilaku atau bagaimana seseorang merespon seseorang dengan cara tertentu

5. Motif (Motive) yaitu sesuatu dimana seseorang secara konsisten berfikir sehingga dapat melakukan tindakan.

Menurut Michael Zwell (2000:309) menyebutkan ada faktor-faktor yang dapat dipergunakan untuk memperbaiki kompetensi yaitu:

1. Admitting Incompetence (Mengalami Kekurangan Kompetensi)

Seringkali terjadi orang menutupi kekurangannya agar tidak diketahui orang lain. Budaya yang berusaha untuk selalu tampil baik mengandung bahaya tidak menyadari kekurangan kecakapan dalam kompetensi. Untuk itu ada baiknya orang mengakui dengan terus terang akan kekurangan dalam kompetensinya sehingga dapat dilakukan usaha untuk memperbaikinya. 


\section{Raising Expectations (Meningkatkan Harapan)}

Pekerjaan manajer dan coach termasuk membantu orang memperluas visi atas pekerjaan mereka sehingga mereka dapat memanfaatkan bakat, kemampuan, dan potensinya. Tugas utama seorang coach adalah menciptakan dan memelihara visi yang lebih tinggi bagi pekerja, dengan menjaga dalam pikirannya apa yang mungkin bagi mereka apabila memanfaatkan semuanya kemampuan dan bakatnya. Coach perlu terus-menerus meningkatkan pekerja atas visinya, mendorong mereka untuk bekerja keras mencapai visi, membantu mereka mencatat kesenjangan antara visi dengan perilaku saat ini, dan membantu mereka mengembangkan tujuan dan langkah tindak untuk mengatasi kesenjangan.

\section{Identifying Barriers (Mengidentifikasi Hambatan)}

Apabila terdapat hambatan terhadap kinerja dan pencapaian prestasi, penting sekali untuk mengidentifikasi sifat dari hambatan tersebut sehingga dapat diatasi secara efektif. Kebanyakan hambatan dapat dikategorikan dalam pengetahuan, keterampilan, proses, dan emosional.

\section{Including Support Mechanism (Memasukkan Mekanisme Dukungan)}

Pada kebanyakan budaya organisasi, penguatan perilaku secara sadar dipergunakan dalam konteks: program disiplin berkaitan dengan masalah pekerja, dan rencana kompensasi dan promosi untuk memberi penghargaan kontributor besar. Dengan secara sadar menggunakan penguatan perilaku dengan lebih kreatif dan meluas, organisasi dapat membantu pekerja memperbaiki kinerja dan kompetensi. Mekanisme dukungan yang dapat dipergunakan organisasi dan pekerja adalah mencatat kemajuan tujuan dan pelaksanaan langkah tindak, mengkomunikasikan kemajuan kepada orang lainnya dan menggunakan penghargaan.

\section{A. Perencanaan Suksesi}

Vincent Gaspersz (2012:144) mengemukakan perencanaan suksesi (succesion planning) adalah suatu proses untuk mengidentifikasi dan mengembangkan orang-orang internal yang berpotensi tinggi (talenta) untuk mengisi posisi kunci atau penting dalam organisasi. Perencanaan suksesi menjamin ketersediaan karyawan yang mampu dan berpengalaman yang dipersiapkan untuk berperan penting di masa yang akan datang. 
Proses suksesi mencakup beberapa langkah berikut :

1. Identifikasi posisi kunci untuk suksesi

2. Identifikasi kompetensi

3. Rencana pembelajaran individu

4. Evaluasi program suksesi

Model perencanaan suksesi ditunjukan dalam bagan, sebagai berikut:

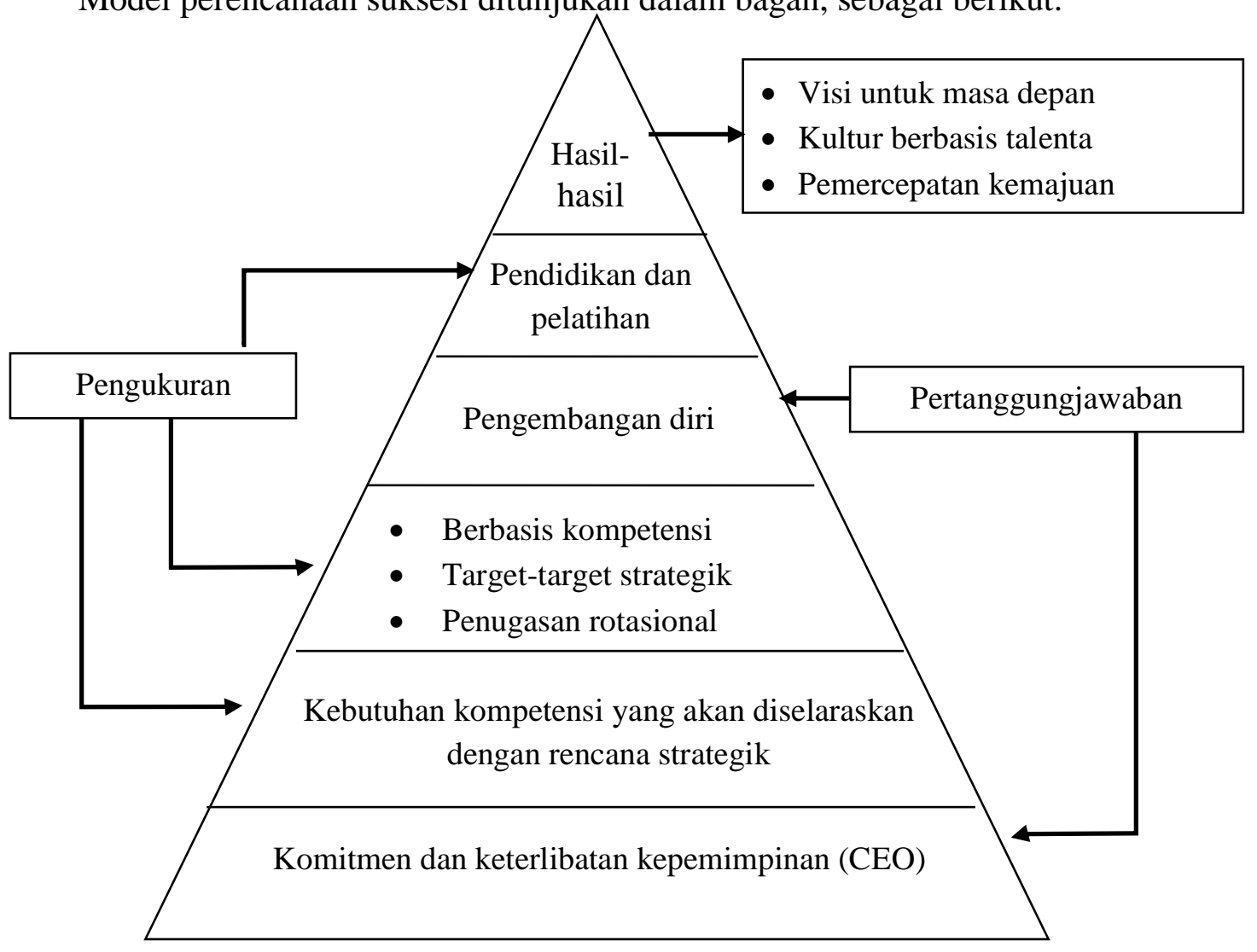

Gambar 1

Bagan Model Perencanaan Suksesi

Sumber: Vincent Gaspersz (2012:151)

\section{B. Pengembangan Karir}

Menurut Noeewll (1998), pengembangan karier merupakan tugas organisasi untuk membentuk hubungan dengan orang yang mengelola kariernya, karena karier tersusun dari pergantian antara individu dan organisasi. Individu merencanakan karier mereka guna meningkatkan status dan gaji mereka, memastikan keselamatan pekerjaan dan mempertahankan kemampuan pasaran mereka dalam pasar tenaga kerja yang berubah. 
Handoko (2000) menyatakan bahwa ada 6 (enam) kegiatan pengembangan karier yang dapat dilakukan masing-masing individu sebagai berikut:

1. Prestasi kerja. Kegiatan paling penting untuk memajukan karier adalah prestasi kerja yang baik karena hal ini mendasari semua kegiatan pengembangan karier lainnya. Kemajuan karier sangat tergantung pada prestasi kerja.

2. Exposure. Kemajuan karier juga ditentukan oleh exposure berarti menjadi dikenal oleh orang-orang yang memutuskan promosi, transfer dan kesempatan-kesempatan karier lainnya. Tanpa exposure, karyawan yang berprestasi baik, mungkin tidak memperoleh kesempatan untuk mencapai sasaran-sasaran kariernya.

3. Permintaan berhenti. Hal ini merupakan suatu cara untuk mencapai sasaran karier, apabila ada kesempatan karier ditempat lain sehingga dengan permintaan berhenti tersebut, yang bersangkutan dapat berpindah tempat bertugas atau bekerja.

4. Kesetiaan organisasional. Kesetiaan pada organisasi dimana seseorang bertugas atau bekerja turut menentukan kemajuan karier yang bersangkutan. Kesetiaan organisasional yang rendah pada umumnya ditemui pada para sarjana baru (yang mempunyai harapan tinggi, tetapi Bering kecewa dengan tempat tugas pertama mereka) dan para profesional (yang kesetiaan pertamanya pada profesinya).

5. Mentor dan sponsor. Para mentor atau pembimbing karier informal bila berhasil membimbing karier karyawan atau pengembangan kariernya lebih lanjut dapat menjadi sponsor mereka. Seorang sponsor adalah orang dalam organisasi yang dapat menciptakan kesempatan-kesempatan pengembangan karier bagi orang lain.

6. Kesempatan untuk tumbuh. Hal ini terjadi, apabila karyawan meningkatkan kemampuan, misalnya melalui program latihan pengembangan kursus-kursus, dan lain-lain. 


\section{Pelatihan}

Menurut Achmad Darodjat, Tubagus (2015:75) pelatihan merupakan salah satu faktor yang perlu menjadi perhatian oleh seorang pimpinan dalam usaha memperoleh program yang diinginkan baik usaha yang bersifat mencari keuntungan maupun usaha yang bersifat pelayanan.

Donald L. Kirkpatrick (1998) mengatakan bahwa evaluasi suatu training adalah bagian yang tidak terpisahkan dari penyelenggaraan training dan evaluasi tersebut merupakan kegiatan yang harus dilakukan agar training secara keseluruhan dapat berlangsung secara efektif. Kirkpatrick mengemukakan teorinya yang terkenal mengenai evaluasi training melalui tulisannya di American Society for Training and Development Journal. Menurutnya, ada 4 tingkat atau level dalam evaluasi training yang kemudian disebut "The Four Levels", yaitu:

\section{Evaluasi Level 1 : Reaction}

Yaitu mengukur reaksi kepuasan peserta terhadap pelaksanaan training. Evaluasi atas reaksi peserta merupakan hal penting untuk dilakukan, karena apabila peserta bereaksi negatif dan tidak menyukai cara-cara penyelenggaraan maka peserta cenderung akan tidak mampu mempelajari dan memahami dengan baik materi training.

\section{Evaluasi Level 2 : Learning}

Yaitu mengukur sejauhmana peserta memahami materi training yang disampaikan dalam tiga domain kompetensi : Knowledge, Skill, dan Attitude. Tiga domain kompetensi : (Knowledge, Skill, dan Attitude) merupakan 3 hal yang dapat diajarkan dalam suatu training. Evaluasi pada level ini menekankan pada seberapa jauh pembelajaran (learning) peserta atas materi dalam konteks peningkatan kompetensi peserta. Menurut Kirkpatrick pentingnya evaluasi ini dilakukan, karena jika peserta tidak dapat memahami dengan baik materi yang diberikan, maka jangan berharap akan terjadi perubahan dalam behavior-nya saat dia kembali ke tempat kerjanya.

\section{Evaluasi Level 3 : Behavior}

Yaitu Mengukur sejauhmana peserta mengimplementasikan pemahaman kompetensi yang diperolehnya dalam lingkungan pekerjaan. Tujuannya untuk mengetahui seberapa jauh perubahan yang terjadi pada eks-peserta pada saat 
mereka kembali ke lingkungan pekerjaannya setelah mengikuti training, khususnya perubahan atas behavior kompetensi (knowledge, skills, dan attitudes).

\section{Evaluasi Level 4 : Result}

Mengukur seberapa besar dampak pelaksanaan training terhadap kinerja pekerjaan ataupun hasil akhir yang diharapkan. Tujuannya untuk mengetahui sampai sejauhmana training yang dilakukan memberikan dampak hasil (results) terhadap peningkatan kinerja eks-peserta, unit kerja, maupun perusahaan secara keseluruhan.

\section{Tabel 1}

\section{Penelitian Terdahulu serta Persamaan dan Perbedaanya Berdasarkan}

Jurnal

\begin{tabular}{|c|c|c|c|c|}
\hline NO & $\begin{array}{c}\text { STUDI } \\
\text { TERDAHULU }\end{array}$ & HASIL PENELITIAN & PERSAMAAN & PERBEDAAN \\
\hline 1 & $\begin{array}{l}\text { Salmah, Ninin } \\
\text { Non Ayu } \\
\text { /"Pengaruh } \\
\text { Program } \\
\text { Pelatihan dan } \\
\text { Pengembangan } \\
\text { Karyawan } \\
\text { Terhadap } \\
\text { Kompetensi } \\
\text { Karyawan pada } \\
\text { PT. Muba } \\
\text { Electric Power } \\
\text { Sekayu"/2012 }\end{array}$ & $\begin{array}{l}\text { Secara simultan pelatihan dan } \\
\text { pengembangan karyawan } \\
\text { berpengaruh secara signifikan } \\
\text { terhadap kompetensi karyawan } \\
\text { PT. Muba Electric Power } \\
\text { Sekayu. Secara Parsial, } \\
\text { variabel pelatihan berpengaruh } \\
\text { signifikan terhadap kompetensi } \\
\text { karyawan, sedangkan variabel } \\
\text { pengembangan karyawan } \\
\text { berpengaruh tidak signifikan } \\
\text { terhadap kompetensi karyawan } \\
\text { PT. Muba Electric Power } \\
\text { Sekayu. }\end{array}$ & $\begin{array}{l}\text { Keduanya } \\
\text { meneliti } \\
\text { mengenai } \\
\text { program } \\
\text { pelatihan dan } \\
\text { kompetensi } \\
\text { karyawan. }\end{array}$ & $\begin{array}{l}\text { Tempat } \\
\text { penelitian } \\
\text { dilakukan } \\
\text { dilokasi yang } \\
\text { berbeda. }\end{array}$ \\
\hline
\end{tabular}

Tabel 2

Penelitian Terdahulu serta Persamaan dan Perbedaanya Berdasarkan Tesis

\begin{tabular}{|c|c|c|c|c|}
\hline NO & STUDI TERDAHULU & $\begin{array}{c}\text { HASIL } \\
\text { PENELITIAN }\end{array}$ & PERSAMAAN & PERBEDAAN \\
\hline 1 & $\begin{array}{lr}\text { Sudrajat, } & \text { Asep } \\
\text { /"Pengaruh } & \text { Kompetensi } \\
\text { Karyawan } & \text { Dan } \\
\text { Lingkungan } & \text { Kerja } \\
\text { Terhadap Kinerja } & \text { Badan } \\
\text { Usaha Milik } & \text { Desa } \\
\text { (BUMNDes) } & \text { di } \\
\text { Kabupaten } & \\
\text { Karawang"/2014 } & \end{array}$ & $\begin{array}{l}\text { Berdasarkan hasil } \\
\text { analisis } \\
\text { menunjukan } \\
\text { bahwa } \\
\text { kompetensi dan } \\
\text { lingkungan kerja } \\
\text { mempunyai } \\
\text { tingkat hubungan } \\
\text { yang rendah } \\
\text { karena nilainya } \\
\text { positif. }\end{array}$ & $\begin{array}{l}\text { Kedua penelitian } \\
\text { bertujuan untuk } \\
\text { mengkaji } \\
\text { mengenai } \\
\text { kompetensi. }\end{array}$ & $\begin{array}{l}\text { Metode penelitian dalam } \\
\text { penelitian ini adalah } \\
\text { deskriptif dan verifikatif } \\
\text { dengan pendekatan } \\
\text { kuantitatif., yaitu untuk } \\
\text { mengetahui ciri-ciri } \\
\text { variabel kompetensi, } \\
\text { lingkungan kerja, kinerja } \\
\text { BUMDes dan pengujian } \\
\text { hipotesis. }\end{array}$ \\
\hline
\end{tabular}




\section{Kerangka Pemikiran}

Dalam kerangka pemikiran teoritis penelitian ini adalah mengenai "Peningkatan kompetensi yang berbasis pelatihan model return on training investmen (ROTI)". sedangkan pada kerangka penelitian konseptual, peneliti ingin mengetahui sejauhmana pelatihan yang diberikan perusahaan untuk meningkatkan kompetensi pegawai yang berkualitas bagi perusahaanya. Hasil kompetensi dapat dijadikan pertimbangan penilaian untuk pimpinan kepada pegawai. Pelatihan yang tepat yang diberikan kepada pegawai adalah pelatihan yang mempertimbangkan berbagai aspek yang dibutuhkan dalam pelatihan tersebut. Dalam penelitian ini, pelatihan yang diberikan kepada pegawai adalah pelatihan yang dilakukan di Perusahaan dan di Instansi Pemerintahan. Penelitian ini menetapkan meningkatkan kompetensi pegawai sebagai hasil akhir dari penelitian ini. Adapun kerangka konseptual yang dikembangkan dalam model ini adalah sebagai berikut:

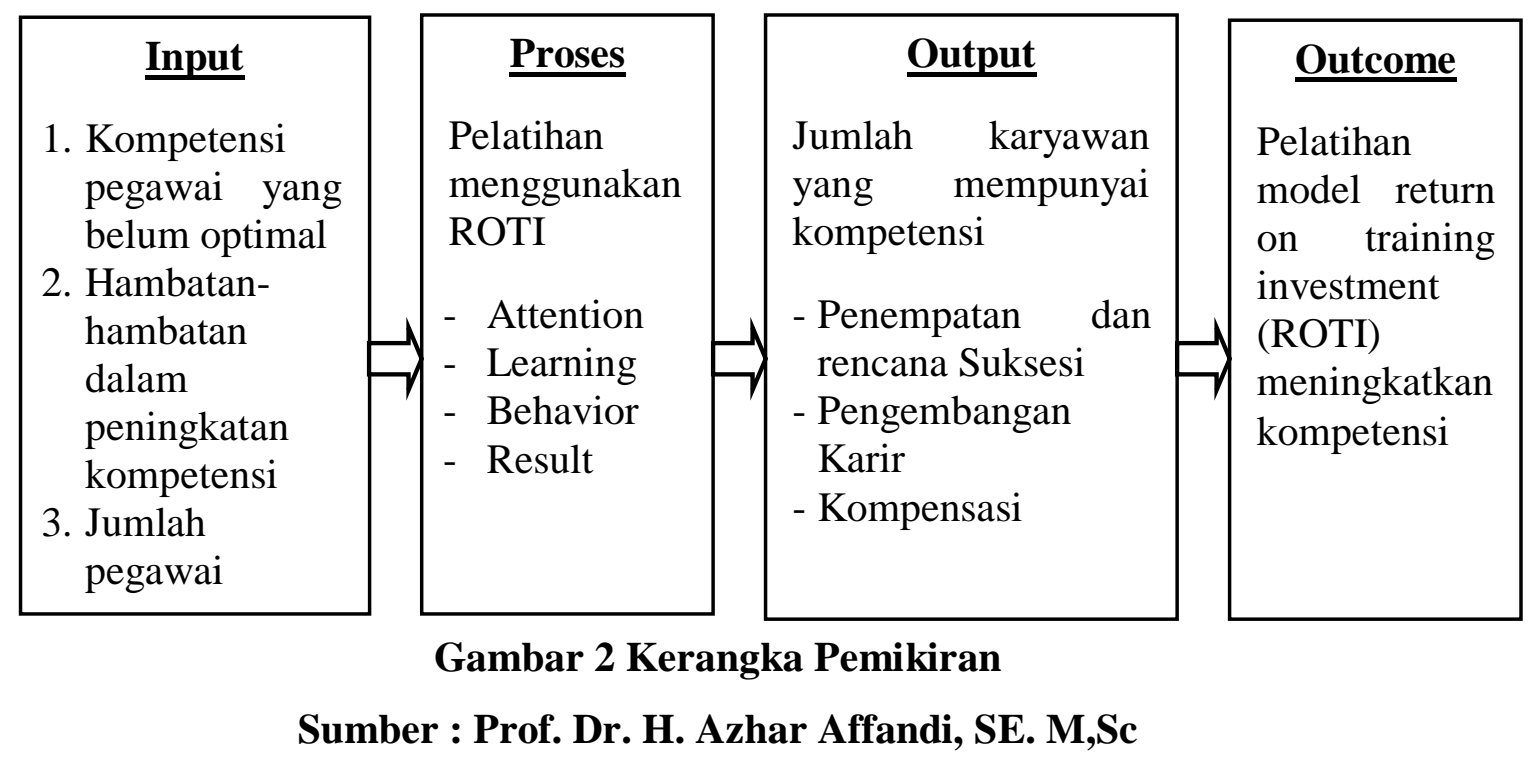

\section{Proposisi}

Proposisi dalam penelitian ini ialah sebagai berikut:

1. Dengan mengetahui kompetensi pada pegawai di PT Alpha Automotive Indonesia dapat diketahui kebutuhan pelatihan pegawai

2. Penerapanpelatihan Model Return On Training Investment (Roti)dapat diterima oleh pegawai PT Alpha Automotive Indonesia 
3. Dengan pelatihan Model Return On Training Investment (Roti) berhasil meningkatkan kompetensi pegawai di PT Alpha Automotive Indonesia

\section{OBJEK DAN METODE PENELITIAN}

\section{Latar Penelitian.}

Dalam penelitian ini, peneliti menggunakan metode kualitatif dikarenakan dalam pembahasan mengenai program peningkatan kompetensi yang berbasis pelatihan model return on training investment di PT.Alpha Automotive Indonesia dan faktor-faktor apa saja yang dapat dipergunakan untuk mengatasi hambatan kompetensi dalam berbagai jenis pelatihan sebagai pencapaian rencana suksesi dan pengembangan karir pegawai untuk meningkatkan kompetensi pegawai PT.Alpha Automotive Indonesia dapat dilakukan dengan atribut dan penulis tidak mencari pengaruh keterkaitan variabel. Yang dikaji secara atribut yaitu peningkatan kompetensi yang berbasis pelatihan di PT.Alpha Automotive Indonesia.

\section{Metode dan Prosedur Penelitian}

Pendekatan penelitian yang digunakan adalah pendekatan kualitatif. Metode kualitatif adalah metode penelitian yang bermaksud untuk memahami fenomena tentang apa yang di alami oleh subjek penelitian. Teknik pengumpulan data yang digunakan dalam penelitian kualitatif adalah wawancara mendalam, observasi partisipasi dan analisis data.

\section{Tempat dan Waktu Penelitian}

Penelitian ini dilakukan di PT. Alpha Automotive Indonesia, Kawasan Industri Kota Bukit Indah Purwakarta, pada tahun 2017. Sedangkan waktu penelitian adalah sejak melakukan observasi awal sebagai persiapan penulisan proposal sampai pada penulisan laporan penelitian. Waktu yang dilaksanakan dalam penelitian, sebagai berikut: 
Tabel 3

Waktu Penelitian

\begin{tabular}{|c|c|c|c|c|c|c|c|c|}
\hline \multirow{2}{*}{ No } & \multirow{2}{*}{ Keterangan } & \multicolumn{7}{|c|}{ Bulan } \\
\hline & & Maret & April & Mei & Juni & Juli & Agustus & September \\
\hline 1 & $\begin{array}{l}\text { Pengumpulan } \\
\text { data, informasi } \\
\text { dan pengolahan } \\
\text { data }\end{array}$ & & & & & & & \\
\hline 2 & \begin{tabular}{lr}
\multicolumn{3}{l}{ Pengumpulan } \\
data melalui \\
observasi dan \\
wawancara
\end{tabular} & & & & & & & \\
\hline 3 & $\begin{array}{l}\text { Pengolahan hasil } \\
\text { penelitian }\end{array}$ & & & & & & & " " \\
\hline 4 & $\begin{array}{l}\text { Penyusunan draf } \\
\text { hasil penelitian }\end{array}$ & & & & & & & \\
\hline
\end{tabular}

Sumber : Dianalis Peneliti, 2017.

Keterangan

Realisasi

\section{Data dan Sumber Data}

Data yang dikumpulkan dalam penelitian ini adalah data primer dan data sekunder. Menurut S. Nasution data primer adalah data yang dapat diperoleh langsung dari lapangan atau tempat penelitian melalui wawancara maupun observasi. Sedangkan data sekunder adalah data-data yang didapat dari bagian perusahaan PT.Alpha Automotive Indonesia, website perusahaan dan majalah perusahaan. Penelitian kualitatif menghasilkan tiga jenis data, berupa catatan lapangan, audio rekaman dan video rekaman, dan transkrip (Emily Name, 2005:12). Dalam pengumpulan informasi dan data dilakukan melalui beberapa cara,yaitu:

1. Data tentang kompetensi sumber daya manusia, faktor-faktor penghambat dalam peningkatan kompetensi di PT.Alpha Automotive Indonesia dan pelatihan yang diterapkan di PT.Alpha Automotive Indonesia,peneliti memperolehnya dari hasil wawancara dengan departemen HR-GA, suporter HR-GA PT.Alpha Automotive Indonesia dan sumber daya manusia yang terkait,yang ditulis dan di rekam oleh video rekaman. Selain itu juga data di ambil melalui observasi langsug di lapangan dan studi dokumentasi. Hal ini 
di dasari bahwa dokumen yang terkait dengan masalah penelitian sangat diperlukan.

2. Sumber data dalam penelitian ini yaitu data pertamakalinya yang diambil oleh peneliti berupa hasil wawancara, hasil observasi, hasil diskusi terkait penilaian kompetensi sumber daya manusia di PT.Alpha Automotive Indonesia, kebutuhan pelatihan di PT.Alpha Automotive Indonesia, promosi jabatan di PT.Alpha Automotive Indonesia. Serta data yang berasal dari studi dokumentasi meliputi aspek profil keorganisasian PT.Alpha Automotive Indonesia.

\section{Teknik dan Prosedur Pengumpulan Data}

\section{Teknik Pengumpulan data}

Untuk memperoleh data yang dibutuhkan peneliti dalam pengumpulan data yang digunakan meliputi:

1. Teknik Observasi; Sugiyono (2012:226) mengemukakan menurut Nasution (1988) observasi adalah dasar semua ilmu pengetahuan. Sanafiah Faisal (1990) mengklasifikasikan observasi menjadi observasi berpartisipasi (participant observation), observasi yang secara terangterangan dan tersamar (overt observationdan convert observation), dan observasi yang tak berstruktur (unstructured observation). Selanjutnya Spradley, dalam susan Stainback (1988) membagi observasi berpartisipasi menjadi empat, yaitu pasive participation, moderate participation, active participation, dan complete participation.

2. Teknik Wawancara; Sugiyono (2012:231) mengemukakan menurut Esterberg (2002) mendefinisikan interview sebagai berikut. “a meeting of two persons to exchange information and idea through question and responses, resulting in communication and joint construction of meaning about a pasrticular topic". Wawancara adalah merupakan pertemuan dua orang untuk bertukar informasi dan ide melalui tanya jawab, sehingga dapat dikonstruksikan makna dalam suatu topik tertentu.

3. Teknik Dokumen; Sugiyono (2012:240) dokumen merupakan catatan peristiwa yang sudah berlalu. Dokumen bisa berbentuk tulisan, gambar, 
atau karya-karya monumental dari seseorangyang semua itu memberikan informasi bagi proses penelitian. Studi dokumen merupakan pelengkap dari penggunaan metode observasi dan wawancara dalam penelitian kualitatif. Pengambilan data dengan dokumentasi dilakukan oleh peneliti dengan cara mengabadikan waktu wawancara dengan foto berdua bersama nara sumber dan membuat rekaman video, dan dengan mendokumentasikan segala kejadian yang berkaitan dengan penelitian.

4. Focus Group Discussion; Focus Group Discussion (FGD) adalah teknik pengumpulan data yang umumnya dilakukan pada penelitian kualitatif dengan tujuan menemukan makna sebuah tema menurut pemahaman sebuah kelompok. Teknik ini digunakan untuk mengungkap permaknaan dari suatu kelompok berdasarkan hasil diskusi yang terpusat pada suatu permasalahan tertentu. FGD juga dimaksudkan untuk menghindari permaknaan yang salah dari seorang peneliti terhadap focus masalah yang sedang diteliti.

\section{Prosedur Pengumpulan data}

Sebelum dilakukan pengambilan data, maka terlebih dahulu ditentukan populasi, sampel dan teknik sampling. Dalam penelitian kualitatif menurut Spradley dalam Sugiyono (2010:49) tidak menggunakan istilah populasi tetapi disebut social situation, yang terdiri dari (1) tempat (place), (2) Pelaku (actors), dan (3) aktivitas (activity) yang berinteraksi secara sinergis. Situasi soasial dalam penelitian ini adalah PT.Alpha Automotive Indonesia, sebagai aktornya yaitu seluruh pegawai mulai direktur, supervisor, pegawai kantor dan seluruh pegawai produksi.

\section{Instrument Penelitian}

Dalam penelitian kualitatif instrumen utamanya adalah peneliti sendiri, namun selanjutnya setelah fokus penelitian menjadi jelas, maka kemungkinan akan dikembangkan instrumen penelitian sederhana, yang diharapkan dapat melengkapi data dan membandingkan dengan data yang telah ditemukan melalui observasi dan wawancara. Peneliti akan terjun ke lapangan sendiri, baik pada 
grand tour question, tahap focused and selection, melakukan pengumpulan data, analisis dan membuat kesimpulan (Sugiyono,2012:222).

Tabel 4

Instrumen Penelitian

\begin{tabular}{|c|c|c|c|c|c|}
\hline No & $\begin{array}{c}\text { Fokus } \\
\text { Penelitian }\end{array}$ & Sub Fokus & $\begin{array}{c}\text { Sumber } \\
\text { Data }\end{array}$ & $\begin{array}{c}\text { Teknik } \\
\text { Pengumpulan } \\
\text { Data }\end{array}$ & Informan \\
\hline 1 & $\begin{array}{l}\text { Kompetensi } \\
\text { Pegawai }\end{array}$ & $\begin{array}{l}\text { - Kompetensi } \\
\text { pegawai } \\
\text { yang belum } \\
\text { optimal } \\
\text { - Hambatan } \\
\text { dalam } \\
\text { peningkatan } \\
\text { kompetensi } \\
\text { - Jumlah } \\
\text { pegawai }\end{array}$ & $\begin{array}{l}\text { Data yang } \\
\text { di dapat } \\
\text { dari } \\
\text { datadokum } \\
\text { entasi atau } \\
\text { arsip } \\
\text { PT.Alpha } \\
\text { Automotive } \\
\text { Indonesia }\end{array}$ & $\begin{array}{l}\text { 1. Observas } \\
\text { 2. Wawancara } \\
\text { 3. Focus } \\
\text { Group } \\
\text { Discussion }\end{array}$ & Divisi HR-GA \\
\hline 2 & $\begin{array}{l}\text { Pelatihanmod } \\
\text { el return on } \\
\text { training } \\
\text { investment }\end{array}$ & $\begin{array}{l}\text { - Attention } \\
\text { - Learning } \\
\text { - Behavior } \\
\text { - Result }\end{array}$ & $\begin{array}{l}\text { Data yang } \\
\text { di peroleh } \\
\text { langsung } \\
\text { dari } \\
\text { lapangan }\end{array}$ & $\begin{array}{l}\text { 1. Observasi } \\
\text { 2. Dokumen }\end{array}$ & $\begin{array}{ll}\text { - } & \text { Instruktur } \\
& \text { Pelatihan } \\
\text { - Penyelenggara } & \text { - Divisi HR-GA }\end{array}$ \\
\hline 3 & $\begin{array}{l}\text { Pelatihan } \\
\text { model return } \\
\text { on training } \\
\text { investment } \\
\text { meningkatkan } \\
\text { kompetensi } \\
\text { pegawai }\end{array}$ & $\begin{array}{l}\text { - Penempatan } \\
\text { dan rencana } \\
\text { suksesi } \\
\text { - Pengemban } \\
\text { gan karier } \\
\text { - Kompensasi }\end{array}$ & $\begin{array}{l}\text { Data Primer } \\
\text { dan Data } \\
\text { Sekunder }\end{array}$ & $\begin{array}{l}\text { 1. Observasi } \\
\text { 2. Wawancara } \\
\text { 3. Focus } \\
\text { Group } \\
\text { Discussion }\end{array}$ & $\begin{array}{l}\text { - Divisi HR-GA } \\
\text { - Pimpinan } \\
\text { - Konsultan } \\
\text { HR-GA }\end{array}$ \\
\hline
\end{tabular}

Sumber : Prof. Dr. H. Azhar Affandi, SE. M,Sc

\section{Prosedur Analisis Data}

1. Analisis sebelum di lapangan

Penelitian kualitatif telah melakukan analisis data sebelum peneliti memasuki lapangan. Analisis dilakukan terhadap data hasil studi pendahuluan, atau data sekunder, yang akan digunakan untuk menentukan fokus penelitian. Namun demikian fokus penelitian ini masih bersifat sementara, dan akan berkembang setelah peneliti masuk dan selama di lapangan.

2. Analisis data di lapangan

a. Analisis data di lapangan model Miles and Huberman 
Miles and Huberman (1984), mengemukakan bahwa aktivitas dalam analisis data kualitatif dilakukan secara interaktif dan berlangsung secara terus menerus sampai tuntas, sehingga datanya sudah jenuh. Aktivitas dalam analisis data menurut Miles and Huberman (1984) dalam Sugiyono (2012:246),yaitu:

1. Reduksi data yaitu proses preduksian data ke dalam bentuk uraian yang lengkap dan banyak.

2. Display data yaitu upaya pembuatan dan penyajian data melalui table sehingga keseluruhan data serta bagian-bagian detailnya dapat dipetakan dengan jelas.

3. Kesimpulan dan verifikasi yaitu penyusunan secara sistematis data yang sudah terkumpul, baik melalui penentuan tema maupun tabel.

Model interaktif dalam analisis data ditunjukan pada gambar.

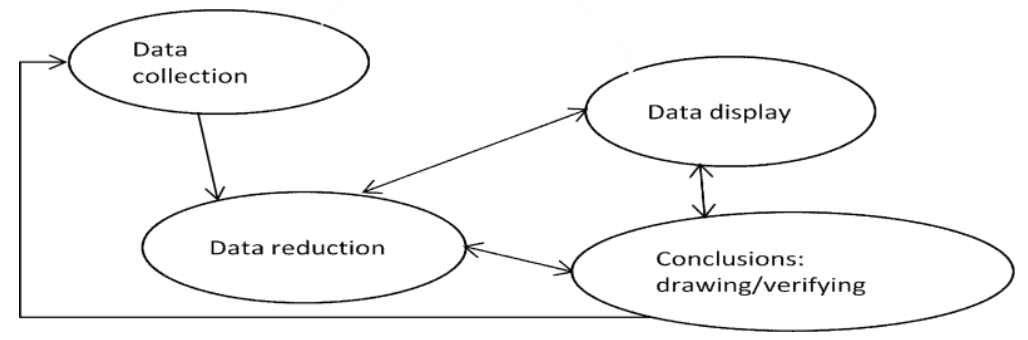

Gambar 3

Komponen dalam analisis data (interactive model)

b. Analisis data di lapangan model Spradley

Spradley (1980) membagi analisis data dalam penelitian kualitatif berdasarkan tahapan dalam penelitian kualitatif. Tahapan penelitian kualitatif menurut Spradley bahwa proses penelitian berawal dari yang luas, kemudian memfokus dan meluas lagi. Tahapan analisis data yang dilakukan dalam penelitian kualitatif, yaitu analisis domain, analisis taksonomi, analisis komponensial, dan analisis tema kultural.

\section{Keabsahan Data}

Sugiyono (2012:269) menyatakan bahwa dalam penelitian kualitatif, kriteria utama terhadap data hasil penelitian adalah valid, reliabel dan obyektif. Pengujian keabsahan data penelitian akan dilakukan dengan cara: 


\section{Kredibilitas (Credibility)}

Uji kredibilitas data, yang terdiri dari beberapa aktivitas sebagai berikut: (Sugiyono, 2012:270).

1. Perpanjangan pengamatan, peneliti kembali lagi ke lapangan melakukan pengamatan untuk mengetahui kebenaran data yang diperoleh maupun untuk menemukan data-data yang baru.

2. Meningkatkan ketekunan, yaitu melakukan pengamatan secara lebih cermat dan berkesinambungan.

3. Triangulasi, William Wiersma dalam Sugiyono (2012:273) menyatakan bahwa triangulasi dalam pengujian kredibilitas ini diartikan sebagai pengecekan data dari berbagai sumber dengan berbagai cara dan berbagai waktu. Dengan demikian terdapat triangulasi sumber, triangulasi teknik pengumpulan data, dan waktu.

4. Analisis kasus negatif adalah kasus yang tidak sesuai atau berbeda dengan hasil penelitian hingga pada saat tertentu. Peneliti mencari data yang berbeda atau yang bertentangan dengan temuan data sebelumnya. Bila tidak ada lagi data yang berbeda Dengan demikian temuan penelitian menjadi lebih kredibel.

5. Menggunakan bahan referensi, yaitu adanya pendukung untuk membuktikan data yang telah ditemukan oleh peneliti, seperti rekaman hasil wawancara. Yaitu video hasil rekaman wawancara dengan staff PC atau suporter HRGA dan wawancara tertulis dengan staff HR-GA pada tanggal 15 Agustus 2017 waktu 12:52 dengan menggunakan Handphone dan kertas A4 lembar wawancara.

6. Mengadakan membercheck, adalah proses pengecekan data yang diperoleh peneliti kepada pemberi data.

Penelitian ini mempunyai kekuatan verifikasi datanya telah memiliki rapport yang baik terhadap subjek dengan mengenal subjek penelitian dalam taraf keterlibatan efektif dalam beberapa sisi kehidupan subjek.

\section{Transferabilitas (Transferability)}

Yaitu memberi uraian yang rinci, jelas, sistematis dan dapat dipercaya. Bila pembaca laporan penelitian dapat memperoleh gambaran yang sedemikian 
jelasnya, "semacam apa" suatu hasil penelitian dapat diberlakukan (transferability), maka laporan tersebut memenuhi standar transferabilitas (Faisal dalam Sugiyono 2012:277)

\section{Dependabilitas (Depenability)}

Pengujian dependabilitas disebut reliabilitas. Suatu penelitian yang reliabel adalah apabila orang lain dapat mengulangi atau mereplikasi proses penelitian tersebut. Dalam penelitian ini, uji depenability dilakukan dengan melakukan audit terhadap keseluruhan proses penelitian. Sering terjadi peneliti tidak melakukan proses penelitian ke lapangan, tetapi bisa memberikan data. Dependabilitas adalah daya konsistensi dari hasil penelitian ini. Standard ini penting karena digunakan untuk meyakinkan pembaca bahwa penelitian yang dilakukan itu konsisten. Satu cara penting yang dilakukan menunjang dependabilitas adalah audit.

\section{Konfirmabilitas (Konfirmability)}

Pengujian konfirmability mirip dengan uji dependability, sehingga pengujiannya dapat dilakukan secara bersamaan. Menguji konfirmability berarti menguji hasil penelitian, dikaitkan dengan proses yang dilakukan. Bila hasil penelitian merupakan fungsi dari proses penelitian yang dilakukan, maka penelitian tersebut telah memenuhi standar konfirmability (Sugiyono, 2012:277).

\section{HASIL DAN PEMBAHASAN}

\section{Latar Sosial}

PT. Alpha Automotive Indonesia adalah perusahaan yang bergerak di bidang otomotif terutama di bidang kunci kendaraan, dan handle pintu kendaraan roda empat (mobil) untuk merek mobil Nissan, mobil Honda dan mobil Mitsubishi yang lokasi perusahaannya masih di Indonesia. Perusahaan ALPHA Grup ini berbasis di Jepang dan didirikan tahun 1923 dengan modal 2,760 Miliar Yen. Dan di bulan Juli tahun 2012 didirikan PT. Alpha Automotive Indonesia di Jawa Barat, Indonesia. Presiden direktur PT. Alpha Automotive Indonesia saat ini Mr.Kimura Tatsuo. PT. Alpha Automotive Indonesia adalah perusahaan yang sudah Global Network dengan memiliki cabang-cabang Alpha group di Negaranegara lain, seperti di Jepang, USA, Meksiko, RRC, Korea, India dan Indonesia.

$-\quad$ Visi 
1. Kemajuan global di bawah konsep "Innovation for Access".

2. Mencapai "Inovasi untuk Akses" untuk menciptakan nilai yang melebihi harapan pelanggan. (Nilai pelanggan = Produk bagus dengan harga wajar)

3. Teruslah mempraktekkan Inovasi, beri perhatian pada kegembiraan bekerja, dan jadikan pertumbuhan diri.

- Misi

1. Terus tumbuh dengan keragaman semua karyawan sebagai sumber kekuatan.

2. Sementara mengejar Produk Bagus dengan Harga Reasonable, berkontribusi pada masyarakat rendah karbon.

3. Ikuti peraturan masyarakat, dan lakukan kegiatan perusahaan "Jujur dan Adil".

\section{Hasil Penelitian}

Hasil penelitian ini meliputi beberapa aspek di PT.Alpha Automotive Indonesia atau di tempat dimana nara sumber bersedia di wawancarai. Pelaku dan nara sumber yang diamati atau di wawancari adalah : departemen HR-GA, suporter HR-GA atau Staff PC. dan nara sumber yang memberikan informasi lewat diskusi : departemen QA. Penelitian, wawancara dan diskusi yang dilakukan mengenai: penyediaan dan pengadaan pelatihan bagi sumber daya manusia, serta faktor-faktor yang menghambat kompetensi dalam upaya peningkatan mutu kompetensi sumber daya manusia di PT.Alpha Automotive Indonesia.

\section{Kompetensi pada pegawai di PT.Alpha Automotive Indonesia}

Kompetensi sumber daya manusia di PT.Alpha Automotive Indonesia di tingkatkan dengan cara memberdayakan sumber daya manusia yang ada dan dibantu untuk meningkatkan skill nya, meskipun belum optimal. Pada penelitian ini, direktur memberikan wewenang kepada manajer dan leader untuk menilai kompetensi pegawai di PT.Alpha Automotive Indonesia. Dan ketika manajer HRGA masih ada di PT.Alpha Automotive Indonesia, kompetensi pegawai itu dinilai dengan bantuan pegawai diberikan coaching atau mentoring oleh manager HRGA, manager HR-GA mengintruksikan ke pegawai harus memahami rincian tugas, memahami target kerja, memetakan knowledge, skill dan sikap dalam 
bekerja, memberikan pelatihan terus menerus oleh Manager HR-GA PT.Alpha Automotive Indonesia. Lokasi pelatihannya ada yang di internal perusahaan PT.Alpha Automotive Indonesia, dan ada yang di eksternal perusahaan Suplier perusahaan, Dinas Tenaga Kerja, lembaga ISO System dan lain-lain. Untuk mendapatkan gambaran yang lebih jelas tentang kompetensi pegawai di PT.Alpha Automotive Indonesia dalam rangka untuk mengetahui kebutuhan pelatihan pegawai dapat di lakukan melalui aspek-aspek sebagai berikut: pengetahuan, kemampuan, pemahaman dan sikap.

Faktor penghambat dalam peningkatan kompetensi ini masih belum optimalnya program pelatihan di PT.Alpha Automotive Indonesia dan terbatasnya jumlah sumber daya manusia yang mendapatkan pelatihan. Dan terdapat faktorfaktor yang digunakan untuk memperbaiki kompetensi yaitu dengan Admitting Incompetence, Raising Expectations, Identifying Barriers, dan Including Support Mechanism.

\section{Penerapan pelatihan model return on training investment di} PT.Alpha Automotive Indonesia

Pelaksanaan program pelatihan pada sumber daya manusia di PT.Alpha Automotive Indonesia dapat dikatakan masih sedikit dan sumber daya manusia yang di ikutkan dalam peserta pelatihan belum semuanya sumber daya manusia yang ada di PT.Alpha Automotive Indonesia ikut pelatihan. Hal ini disebabkan karena perusahaan masih baru dan sumber daya manusia yang berkerja masih sedikit, dan dapat dikatakan program pelaksanaan pelatihan yang sudah diberikan kepada sumber daya manusia dapat dilaksanakan dengan baik. Karena pelatihan yang dilaksanakan PT.Alpha Automotive Indonesia didukung dengan evaluasi program pelatihan yaitu Attention, Learning, Behavior dan Result. Selain itu, PT.Alpha Automotive Indonesia melakukan pelatihan atau training yang biasa diselenggarakan, diantaranya skill training, retraining, cross functional training, creativity training dan team training.

\section{Pelatihan model return on training investment berhasil meningkatkan} kompetensi pegawai di PT.Alpha Automotive Indonesia

Upaya-upaya yang dilakukan peningkatan kompetensi setelah pelatihan di PT.Alpha Automotive Indonesia bukan dengan penempatan dan rencana suksesi, 
melainkan tetap menetapkan sumber daya manusia pada departemennya atau dikembangkan karirnya.

\section{Pembahasan}

Dari semua informan menyatakan bahwa benar persfektif teori kompetensi dapat meningkatkan kompetensi pegawai, terbukti setelah ada beberapa pegawai mengikuti pelatihan yang diberikan oleh perusahaan melalui penyelenggara pelatihan seperti pelatihan forklip, pelatihan ISO dan pelatihan yang di adakan di dalam oleh perusahaan seperti pelatihan training perdepartemen.

Peneliti juga menemukan adanya data kompetensi yang sebanding dengan aktualisasi pelatihan pegawai yang menyatakan adanya suatu kebenaran bahwa pelatihan pegawai PT Alpha Automotive Indonesia dapat meningkatkan kompetensi pegawai adalah melalui produktifitas kinerja dan produktifitas skil (kemampuan) yang menunjukan grafik kompetensi pegawai meningkat.

\section{Kompetensi pada pegawai di PT.Alpha Automotive Indonesia}

Kompetensi merupakan keterampilan yang harus dimiliki oleh seluruh pegawai, dimana seorang direktur PT.Alpha Automotive Indonesia melibatkan manager, supervisor, staff untuk meningkatkan kompetensi pegawainya agar tujuan perusahaan tercapai, bisa tumbuh dan berkembang dalam jangka panjang. Berikut beberapa cara yang digunakan PT.Alpha Automotive Indonesia dalam upaya meningkatkan kompetensi pegawai, sebagai berikut :

1. Memahami struktur organisasi perusahaan. Direktur PT.Alpha Automotive Indonesia membuat struktur organisasi dan menginformasikan ke pegawai, agar pegawai bisa memahami dan menerima struktur organisasi, tujuannya untuk peningkatan kompetensi pegawai yang relevan dengan knowledge, skill dan attitude.

2. Memahami job description. Pegawai PT.Alpha Automotive Indonesia dapat memahami gambaran tugasnya masing-masing, sehingga tidak terjadi gap pekerjaan.

3. Memahami target yang harus dicapai oleh pegawai.

4. Memetakan knowledge, skill dan attitude yang dibutuhkan oleh karyawan untuk menjalankan pekerjaan. 
5. Memberikan pelatihan secara berkelanjutan. Direktur PT.Alpha Automotive Indonesia dalam memberikan program pelatihan bagi pegawainya dengan melibatkan pihak internal yaitu manager PT.Alpha Automotive Indonesia, dan pihak eksternal yaitu lembaga pemerintahan (Dinas tenaga kerja) dan supplier perusahaan sebagai trainer bagi pegawainya.

6. Memberikan coaching dan mentoring.

7. Melakukan evaluasi dan mengambil langkah perbaikan terus menerus.

Sedangkan aspek lain yang ditempuh oleh PT.Alpha Automotive Indonesiadalam meningkatkan kompetensi dan untuk mengetahui kebutuhan pelatihan pegawai PT.Alpha Automotive Indonesia dapat dilakukan melalui aspek-aspek sebagai berikut :

1. Pengetahuan. Upaya untuk meningkatkan pengetahuan pegawai di PT.Alpha Automotive Indonesia dapat ditempuh melalui jalur pendidikan dan pelatihan. Dengan tujuan untuk menambah kompetensi pegawai dalam melakukan pekerjaan agar nantinya dapat menjadikan sebagai sumber tenaga profesional. Dengan pengetahuan pegawai diharapkan dapat menunjang kinerja lebih baik, sehingga mampu membawa perubahan kearah efektifitas dan efisiensi dalam pelaksanaan kegiatan organisasi. Dengan pengetahuan yang dimiliki oleh pegawai dapat merubah sikap mental dan prilaku serta membentuk kepribadian pegawai agar dalam menjalankan tugas mampu menghindarkan diri dari praktek.

2. Kemampuan. Menunjukan suatu kompetensi yang dimiliki oleh pegawai dalam melaksanakan tugas atau pekerjaan yang dibebankan. Hal tersebut tercermin dari pelaksanaan kerja yang di bebankan kepada pegawai masih ada yang terlambat selesai, disebabkan karena kemampuan mereka dalam berkerja kurang.

3. Pemahaman. Pemahaman pegawai akan tugas dan tanggung jawabnya merupakan suatu cara yang dapat mendorong perilaku seseorang dalam bidang tertentu.

4. Sikap. Sikap pegawai merupakan suatu bentuk perasaan atau reaksi terhadap suatu rangsangan yang datang dari luar. Pegawai dibutuhkan sikap yang tegas, termotivasi serta pegawai yang memiliki dedikasi yang tinggi dalam 
melaksanakan pekerjaan. Dalam hal ini sikap pegawai PT.Alpha Automotive Indonesia dalam melaksanakan pekerjaan belum sepenuhnya menunjukan sikap atau prilaku kerja yang dapat menunjang terciptanya peningkatan kinerja. Namun secara aplikatif sikap pegawai dalam berkerja sebagian besar memenuhi kualifikasi yang diinginkan.

Dalam penelitian ini, sumber daya manusia atau pegawai harus memiliki kompetensi yang tinggi untuk meningkatkan skill atau kinerjanya mereka agar terlaksana dengan baik. Dasar dari meningkatnya skill pegawai atau kompetensi pegawai di dapat dari program prusahaan dengan mengetahui kompetensi pegawai untuk diadakan pelatihan atau training mendalam kepada masing-masing pegawai. Agar kompetensi pegawai tetap meningkat, penulis menyajikan cara mengatasi hambatan kompetensi, menurut Michael Zwell (2000:309) menyebutkan adanya faktor-faktor yang dapat dipergunakan untuk memperbaiki kompetensi yaitu:

\section{Admitting Incompetence (Mengalami Kekurangan Kompetensi)}

Seringkali terjadi orang menutupi kekurangannya agar tidak diketahui orang lain. Budaya yang berusaha untuk selalu tampil baik mengandung bahaya tidak menyadari kekurangan kecakapan dalam kompetensi. Untuk itu ada baiknya orang mengakui dengan terus terang akan kekurangan dalam kompetensinya sehingga dapat dilakukan usaha untuk memperbaikinya.

\section{Raising Expectations (Meningkatkan Harapan)}

Pekerjaan manajer dan coach termasuk membantu orang memperluas visi atas pekerjaan mereka sehingga mereka dapat memanfaatkan bakat, kemampuan, dan potensinya. Tugas utama seorang coach adalah menciptakan dan memelihara visi yang lebih tinggi bagi pekerja, dengan menjaga dalam pikirannya apa yang mungkin bagi mereka apabila memanfaatkan semuanya kemampuan dan bakatnya.

Coach perlu terus-menerus meningkatkan pekerja atas visinya, mendorong mereka untuk bekerja keras mencapai visi, membantu mereka mencatat kesenjangan antara visi dengan perilaku saat ini, dan membantu mereka mengembangkan tujuan dan langkah tindak untuk mengatasi kesenjangan.

\section{Identifying Barriers (Mengidentifikasi Hambatan)}


Apabila terdapat hambatan terhadap kinerja dan pencapaian prestasi, penting sekali untuk mengidentifikasi sifat dari hambatan tersebut sehingga dapat diatasi secara efektif. Kebanyakan hambatan dapat dikategorikan dalam pengetahuan, keterampilan, proses, dan emosional.

\section{Including Support Mechanism (Memasukkan Mekanisme Dukungan)}

Pada kebanyakan budaya organisasi, penguatan perilaku secara sadar dipergunakan dalam konteks: program disiplin berkaitan dengan masalah pekerja, dan rencana kompensasi dan promosi untuk memberi penghargaan kontributor besar. Dengan secara sadar menggunakan penguatan perilaku dengan lebih kreatif dan meluas, organisasi dapat membantu pekerja memperbaiki kinerja dan kompetensi. Mekanisme dukungan yang dapat dipergunakan organisasi dan pekerja adalah mencatat kemajuan tujuan dan pelaksanaan langkah tindak, mengkomunikasikan kemajuan kepada orang lainnya dan menggunakan penghargaan.

Implementasi kompetensi sumber daya manusia yang harus ada di PT.Alpha Automotive Indonesia dengan adanya kemampuan kompetensi yang dimiliki masing-masing pegawai. Interpretasi pada pembahasan ini menunjukan tentang nilai kompetensi pegawai yaitu: kompetensi tinggi dan kompetensi rendah.

Dalam pembahasan ini penulis kaitkan dengan kajian manajemen sumber daya manusia berbasis kompetensi, sebagai berikut:

1. Bagi eksekutif, Kompetensi yang diperlukan bagi eksekutif adalah:

a) Strategic thinking merupakan kemampuan eksekutif untuk memahami kecenderungan perubahan lingkungan yang cepat, melihat peluang mendeteksi ancaman kompetitif dan kekuatan, kelemahan organisasi mereka, untuk mengidentifikasi respon strategi optimumnya.

b) Change leadership merupakan kompetensi untuk mengkomunikasikan visi dan strategi perusahaan dapat ditransformasikan kepada pegawai.

c) Relationshipmanagement merupakan kemampuan untuk meningkatkan hubungan dan jaringan dengan stakeholders di dalam maupun di luar organisasi.

2. Bagi manajer, kompetensi yang diperlukan bagi manajer adalah: 
a) Flexibility merupakan kemampuan untuk mengubah struktur dan proses manajerial apabila diperlukan untuk menjalankan strategi perubahan organisasi.

b) Change implementation merupakan kemampuan kepemimpinan perubahan untuk mengomunikasikan kebutuhan organisasi akan perubahan kepada bawahan, dan keterampilan manajemen perubahan.

c) Enterpreneurial innovation merupakan motivasi untuk memelopori dan mengungguli dengan memunculkan produk baru mendahului pesaingnya dan dalam memberikan pelayanan dan proses produksi yang semakin efisien.

d) Interpersonal understanding merupakan kemampuan untuk memahami dan menilai masukan dari orang lain yang berbeda.

e) Empowering atau pemberdayaan.

f) Team facilitation merupakan kemampuan untuk menyatukan orang untuk bekerja sama secara efektif dalam mencapai tujuan bersama.

g) Portability merupakan kemampuan untuk beradaptasi dan berfungsi secara efektif dengan lingkungan luar negeri sehingga manajer harus "portable" terhadap posisi-posisi yang ada di negara manapun.

3. Bagi pegawai, kompetensi yang diperlukan bagi pegawai adalah:

a) Flexibility (fleksibilitas).

b) Information-seeking motivation and ability to learn (motivasi mencari informasi dan kemampuan belajar).

c) Achievement motivation (motivasi berprestasi).

d) Collaborativeness (kesediaan bekerja sama).

e) Customer service orientation (orientasi pada pelayanan pelanggan).

Verifikasi dari pembahasan ini dapat dicocokan dengan teori kompetensi menurut Boyatzis dalam Hutape dan Nurianna Thoha (2008) bahwa kompetensi adalah kapasitas yang ada pada sesorang yang bisa membuat orang tersebut mampu memenuhi apa yang disyaratakan oleh pekerjaan dalam suatu oranisasi sehingga organisasi tersebut mampu mencapai hasil yang diharapkan. Kepribadian yang mendalam dan melekat pada seseorang dengan perilaku yang dapat diprediksikan pada berbagai keadaan dan tugas pekerjaan. Prediksi siapa 
yang berkinerja baik dan kurang baik dapat diukur dari kriteria atau standar yang digunakan. Skill adalah kemampuan untuk melaksanakan suatu tugs dengan baik.

Dari hasil yang ada menunjukan kebutuhan pelatihan pegawai dapat diketahui setelah manajemen mengetahui kemampuan kompetensi pegawai yang dimiliki sekarang. Interaksi dari informan sebagai manajemen bahwa melalui pelatihan atau training yang diberikan dan terpenuhi dapat menghasilkan kemampuan masing-masing pegawai yang maksimal, karena kemampuan yang diberikan masing-masing pegawai ke perusahaan adalah sebagai bentuk kompetensi.

\section{Penerapan pelatihan model return on training investment di PT.Alpha Automotive Indonesia}

Program PT.Alpha Automotive Indonesia dalam mengembangkan sumber daya manusia (pegawai) yaitu dengan usaha menghilangkan terjadinya (gap) antara kemampuan yang dimiliki seseorang tenaga kerja dengan target kerja yang dikehendaki organisasi. Usaha tersebut dilakukan melalui peningkatan kompetensi pegawai dengan cara menambah pengetahuan pegawai PT.Alpha Automotive Indonesia dan keterampilannya pegawai PT.Alpha Automotive Indonesia.

Untuk mengembangkan kapabilitas pegawai PT.Alpha Automotive Indonesia seorang direktur PT.Alpha Automotive Indonesia melakukan penerapan program pelatihan sesuai kebutuhan pegawai ditunjang setelah adanya nilai kompetensi pegawai. Pelatihan merupakan proses belajar mengajar dengan mempergunakan teknik dan metode tertentu untuk meningkatkan kompetensi pegawai. Pelatihan memberikan para pegawai pengetahuan yang spesifik dan dapat diketahui.

Menurut Donald L. Kirkpatrick (1998) mengatakan bahwa evaluasi training adalah bagian yang tidak terpisahkan dari penyelenggaraan training dan evaluasi tersebut merupakan kegiatan yang dharus dilakukan agar training secara keseluruhan dapat berlangsung secara efektif. Program pertama pada tahun 1957, dan sampai sekarang termasuk model yang paling sering digunakan di berbagai negara. Beliau merumuskan bahwa evaluasi program pelatihan dapat di klarifikasikan menjadi empat level, yaitu Attention, Learning, Behavior dan Result. 
1. Attention, suatu pelatihan akan berhasil bila direspon positif oleh peserta pelatihan. Pegawai PT.Alpha Automotive Indonesia yang ditugaskan untuk mengikuti pelatihan di internal perusahaan dan eksternal perusahaan dinilai positif dengan menyimak pelatihan yang berjalan.

2. Learning, bila respon positif maka proses belajar mengajar akan berjalan dengan baik. Pelatihan yang diikuti pegawai PT.Alpha Automotive Indonesia berjalan lancar.

3. Behavior, bila proses belajar mengajar berjalan dengan baik maka akan menghasilkan perubahan behavior berupa skill, knowledge dan attitude. Pegawai PT.Alpha Automotive Indonesia yang diberikan pelatihan, kompetensinya dapat meningkat.

4. Result, bila behavior terjadi perubahan positif maka akan menghasilkan kinerja yang lebih baik setelah mengikuti pelatihan. Setelah pegawai PT.Alpha Automotive Indonesia diberikan pelatihan, skill pegawai menjadi lebih baik dari sebelumnya.

Evaluasi program pelatihan ditinjau dari aspek financial yang populer disebut return on training investment digagas oleh Jack Philips pada tahun 2000. Model ini merupakan penyempurna dari Kirkpatrick model, sehingga dapat dikatakan bahwa return on training investment merupakan level $\mathrm{V}$ dari Kirkpatrick model. Dalam hal ini, biaya yang dikeluarkan oleh PT.Alpha Automotive Indonesia dalam program pelatihan pegawai di eksternal perusahaan, untuk pelatihan atau training Forklip sebanyak Rp.2.000.000, pelatihan ISO sebesar biaya tidak diketahui, biaya berkala untuk pelatihan dan kegiatan pimpinan di Wisma Kota Bukit Indah, dan tidak ada biaya untuk pelatihan atau training pegawai di PT.Nissan Motors Indonesia, dan di internal perusahaan PT.Alpha Automotive Indonesia.

Selain itu, PT.Alpha Automotive Indonesia melakukan pelatihan atau training yang biasa diselenggarakan, diantaranya adalah :

\section{Skill Training}

Skill training atau yang dikenal juga dengan pelatihan keahlian adalah jenis training yang diadakan dengan tujuan agar peserta mampu menguasai sebuah skill atau keterampilan baru yang berhubungan dengan 
pekerjaaannya. Keahlian yang diajarkan dalam training biasanya akan diberikan kepada pegawai yang dianggap belum menguasai atau masih kurang nilainya dalam sebuah keahlian tertentu. Contoh training manajemen atau training leadership.

2. Retraining

Retraining atau pelatihan ulang adalah training sumber daya manusia yang diberikan kepada pegawai untuk menghadapi tuntutan kerja yang semakin berkembang. Pegawai harus selalu menyesuaikan diri dengan kemajuan jaman dan inovasi terbaru sehingga pegawai memiliki kompetensi yang tidak kalah dengan pegawai-pegawai di perusahaan lain.

3. Cross Functional Training

Cross functional training merupakan training yang dilakukan dengan meminta pegawai untuk melakukan aktivitas pekerjaan tertentu diluar bidang pekerjaan yang ditugaskan kepadanya. Sehingga pegawai mampu memahami cara kerja organisasi perusahaan secara lebih luas tidak hanya berkutat pada tugas kerjanya saja. Contoh meminta staff bagian departemen PC untuk membantu tugas staff HR-GA dalam menyeleksi karyawan baru.

4. Creativity Training

Training kreatifitas merupakan sebuah training sumber daya manusia yang bertolak belakang dari anggapan bahwa kreatifitas sebenarnya bukan bakat melainkan sebuah skill yang bisa dipelajari. Di PT.Alpha Automotive Indonesia seorang manager, supervisor, staff dan leader. Mereka dituntut untuk bisa kreatif dalam memimpin anak buahnya serta bisa kreatif membuat ide-ide baru yang segar dan inovatif untuk kepentingan perusahaan. Training kreatifitas ini ditunjang dengan kebebasan berpendapat dan mengeluarkan gagasan selama gagasan dan pendapat tersebut rasional, penuh perhitungan, dan sudah dikalkulasi untung ruginya bagi perusahaan.

5. Team Training 
Dalam sebuah perusahaan karyawan tidak hanya dituntut untuk berkerja secara tim dalam sebuah divisi, bagian, dan bahkan dituntut untuk bisa berkerja dalam keseluruhan tim organisasi perusahaan. Training sumber daya manusia yang satu ini ditunjukan bagi sekelompok pegawai agar mereka bisa terbiasa berkerja dalam tim, mampu menempatkan diri dalam sebuah tim, dan mampu berkerjasama dengan anggota tim yang lainnya sehingga pekerjaan dan tujuan bisa diselesaikan dengan lebih cepat dan efektif.

Interpretasi pada pembahasan ini menunjukan tentang pelatihan itu penting diadakan disetiap perusahaan, dengan pelatihan pegawai dapat bekerja dengan tenang dan dapat meningkatkan kemampuan atau skill pegawai dalam bekerja.

Verifikasi dari pembahasan ini dapat dicocokan dengan pelatihan menurut Good, 1973 adalah suatu proses membantu orang lain dalam memperoleh skill dan pengetahuan (M. Saleh Marzuki, 1992:5). Sedangkan Michael-J Jucius dalam Moekijat (1991:2) menjelaskan istilah latihan untuk menunjukan setiap proses untuk mengembangkan bakat, keterampilan dan kemampuan pegawai guna menyelesaikan pekerjaan-pekerjaan tertentu. Dalam PP RI nomor 71 tahun 1991 pasal 1 disebutkan, latihan kerja adalah keseluruhan kegiatan untuk memperoleh, meningkatkan serta mengembangkan produktivitas, disiplin sikap kerja dan etos kerja pada tingkat ketermpilan tertentu berdasarkan persyaratan jabatan tertentu yang pelaksanaannya lebih mengutamakan praktek daripada teori.

Interaksi dari informan sebagai manajemen bahwa melalui pemberian pelatihan atau training kepada pegawai dapat diterima dengan baik oleh pegawai, karena kebutuhan sudah diberikan oleh perusahaan sebagai bentuk program dari perusahaan. Dari hasil yang ada menunjukan penerapan pelatihan model return on training investmen dapat diterima oleh pegawai.

\section{Pelatihan model return on training investment berhasil meningkatkan} kompetensi pegawai di PT.Alpha Automotive Indonesia

Data yang dicari pada proposisi ketiga adalah data yang menunjukan adanya jumlah pegawai yang mempunyai kompetensi yang mengikuti program pelatihan dari perusahaan. Interpretasi pada pembahasan ini menunjukan tentang penempatan dan rencana suksesi, pengembangan karir dan kompensasi. Pimpinan 
di perusahaan berperan sangat tinggi dalam penempatan jabatan pegawai dan pengembangan karir. Pengembangan karir pegawai hanya bisa dengan diberikan pelatihan atau training dan penempatan dibagian yang sesuai dengan potensinya. Selain itu, jika pemberian pelatihan atau trainingdapat diterima pegawai dan dapat meningkatkan kompetensi (skill) pegawai, maka perusahaan akan menaikan kompensasi pegawai melalui kenaikan gaji.

Pengembangan karir di PT.Alpha Automotive Indonesia diartikan sebagai karier (career). Ada dua fokus utama di dalam karier yaitu :

1. Fokus eksternal, fokus eksternal mengarah pada rangkaian kedudukan yang secara aktual dijabat oleh seorang pekerja.

2. Fokus Internal, fokus internal menunjukkan pada cara seseorang memandang kariernya.

Di dalam program pelatihan dan pengembangan yang pernah ada di PT.Alpha Automotive Indonesia, ada dua kategori pokok :

1. On the Job Traning (OTJ)
a) Rotasi Jabatan
b) Instruksi Pekerjaan
c) Penugasan sementara

2. Off the Job training

a. Simulasi

- Role goverment

- Training atau pelatihan

b. Presentasi Informasi

- Alpha Way Alpha Group

- Idea Contest Alpha Group

- Self studi

- Programmed Instruction

Verifikasi dari pembahasan ini dapat dicocokan dengan analisa kompetensi disusun sebagian besar untuk pengembangan karier, dan teori kompetensi menurut Maliki;2013 sistem kompetensi berbasis pelatihan merupakan suatu pendekatan pelatihan yang diarahkan kepada hasil yang spesifik dan terukur bagi pembelajar yang dilandasi oleh deskrispsi spesifik tentang performa kerja sesungguhnya. 
Sistem pelatihan tersebut tidak hanya mengajarkan sesuatu tentang materi-materi pelatihan yang terkait dengan kinerja suatu pekerjaan, akan tetapi juga bagaimana mengidentifikasi level kompetensi yang dibutuhkan untuk level kinerja yang berbeda dalam suatu fungsi tertentu. Dengan melihat kompetensi yang diperlukan untuk level jabatan yang berbeda kita dapat memberikan pilihan kepada para pegawai untuk menentukan tujuan pengembangan profesi mereka inginkan. Yang lebih penting lagi pelatihan berbasis kompetensi akan lebih memberikan banyak praktik dari pada teori, sehingga para peserta akan menjadi tranfil dan mahir menguasai bidang yang dipilihnya dan sesuai dengan kebutuhan perusahaan dimana mereka bekerja dan juga sesuai dengan tuntutan standard yang berlaku untuk jabatan yang ditempatinya.

Kedua subjek menginterpretasikan kebijaksanaan pimpinan mengadakan pelatihan untuk pegawai terhadap diri subjek sebagai wujud penerimaan terhadap keberadaan diri subjek. Ini membuat subjek memiliki harga diri yang tinggi. Kebijaksanaan pimpinan dalam mengadakan pelatihan atau training yang diberikan kepada pegawai membuat subjek termotivasi, sikap baik dan positif yang ia dapatkan dari pimpinannya membuat subjek tumbuh dengan aktualisasi diri yang cenderung positif. Kesemuanya itu tidak lain hanya merupakan implementasi peran seorang top management sebagai upaya memenuhi kebutuhan pengetahuan pegawai dalam meningkatkan kompetensi pegawai tersebut dapat bekerja dengan giat, tekun, nyaman, dan cepat dalam bekerja, hal ini secara tidak langsung akan mempengaruhi terhadap kemampuan atau kompetensi yang maksimal.

Interaksi dari informan sebagai manajemen bahwa melalui kebutuhan yang sudah diberikan dengan pelatihan atau training yang diberikan dan terpenuhi dapat disikapi positif oleh pegawai yang mengikuti pelatihan dan dapat disikapi positif oleh manajemen, karena kebutuhan sudah diberikan oleh perusahaan sebagai bentuk untuk meningkatkan kompetensi atau skill pegawai. Dari hasil yang ada di dapat berdasarkan pelatihan yang diberikan kepada pegawai adalah sebagai bentuk peningkatan kompetensi.

\section{SIMPULAN DAN REKOMENDASI}

\section{Kesimpulan}


Berdasarkan uraian pada hasil peneltiian dan pembahasan sebagaimana disajikan pada bab sebelumnya, maka dapat ditarik kesimpulan sebagai berikut:

1. Kompetensi pegawai di PT.Alpha Automotive Indonesia

Kompetensi sumber daya manusia di PT.Alpha Automotive Indonesia di bentuk oleh direktur dan manajer dengan memberikan proses-proses pencapaian peningkatan kompetensi dengan jenis program pelatihan. Program pelatihan yang dimaksud ada yang di internal perusahaan dan ada yang di eksternal perusahaan. Hal ini sesuai dengan teori Spencer dan Spencer dalam Palan (2007) dan Boyatzis dalam Hutape dan Nurianna Thoha (2008) bahwa kompetensi pegawai bisa meningkat setelah pegawai diberikan pelatihan, diberikan dorongan dan arahan dari atasan.

2. Penerapan pelatihan model return on training investment di PT.Alpha Automotive Indonesia

Donald L. Kirkpatrick (1998) merumuskan bahwa evaluasi program pelatihan dapat di klarifikasikan menjadi empat level, yaitu :

1. Attention, Pegawai PT.Alpha Automotive Indonesia yang ditugaskan untuk mengikuti pelatihan di internal perusahaan dan eksternal perusahaan dinilai positif dengan menyimak pelatihan yang berjalan.

2. Learning, Pelatihan yang diikuti pegawai PT.Alpha Automotive Indonesia berjalan lancar.

3. Behavior, Pegawai PT.Alpha Automotive Indonesia yang diberikan pelatihan, kompetensinya dapat meningkat.

4. Result, Setelah pegawai PT.Alpha Automotive Indonesia diberikan pelatihan, skill pegawai menjadi lebih baik dari sebelumnya.

Evaluasi program pelatihan ditinjau dari aspek financial yang populer disebut return on training investment digagas oleh Jack Philips pada tahun 2000. Model ini merupakan penyempurna dari Kirkpatrick model, sehingga dapat dikatakan bahwa return on training investment merupakan level V dari Kirkpatrick model. Dalam hal ini, biaya yang dikeluarkan oleh PT.Alpha Automotive Indonesia dalam program pelatihan pegawai adalah:

- Eksternal perusahaan, untuk pelatihan atau training Forklip sebanyak Rp.2.000.000, pelatihan ISO sebesar biaya tidak diketahui. 
- Eksternal perusahaan, tidak ada biaya bagi trainernya perusahaan suplier PT.Alpha Automotive Indonesia.

- Internal perusahaan, tidak ada biaya untuk pelatihan di dalam perusahaan tempat pegawainya berkerja yaitu di PT.Alpha Automotive Indonesia.

Berdasarkan hasil penelitian pelatihan pegawai di PT. Alpha Automotive Indonesia, pelatihan dinyatakan baik dan dapat diterima oleh pegawai. Hal ini sesuai teori Good, 1973 dan Michael-J Jucius dalam Moekijat (1991:2) dinyatakan baik setelah diketahui kompetensi yang dimiliki pegawai.

3. Pelatihan model return on training investment berhasil meningkatkan kompetensi pegawai di PT.Alpha Automotive Indonesia

Berdasarkan hasil penelitian kompetensi yang berbasis pelatihan pegawai di PT. Alpha Automotive Indonesia dinyatakan berhasil meningkatkan kompetensi pegawai PT. Alpha Automotive Indonesia dengan menunjukan hubungan baik antara pelatihan yang dibutuhkan oleh perusahaan (pelatihan dari luar) dan pelatihan yang di adakan oleh perusahaan.

\section{Rekomendasi}

Berdasarkan penelitian yang telah dilakukan, maka penulis mencoba memberikan beberapa rekomendasi yang bermanfaat, yaitu:

1. Pimpinan dalam perdepartemen PT Alpha Automotive Indonesia harus lebih intensif mengarahkan pegawai dalam pengembangan skill atau peningkatan kompetensi

2. Pimpinan dalam organisasi PT Alpha Automotive Indonesia hendaknya memberikan perhatian yang lebih terhadap aspek pelatihan dalam rangka meningkatkan kompetensi pegawai sehingga tujuan organisasi perusahaan apat dicapai dengan baik dan optimal.

3. Variabel pelatihan mempunyai keterkaitan dengan peningkatan kompetensi pegawai PT Alpha Automotive Indonesia. Oleh karena itu hendaknya semua pihak yang ada dalam organisasi PT Alpha Automotive Indonesia, mulai dari pimpinan tinggi hingga pegawai ditingkat yang 
paling rendah dapat sama-sama berupaya untuk terus meningkatkan kompetensi dan diharapkan skill yang dihasilkan dapat lebih baik.

4. Diperlukan penelitian lanjutan tentang faktor-faktor lain yang mungkin mempunyai keterkaitan dengan pengembangan kompetensi dan pelatihanpelatihan sehingga dapat mengembangkan dan meningkatkan kompetensi pegawai PT Alpha Automotive Indonesia.

\section{DAFTAR PUSTAKA}

\section{Buku dan Jurnal}

Achmad Darodjat, Tubagus. 2015. Konsep-Konsep Dasar Manajemen Personalia Masa Kini. Bandung: PT. Refika Aditama

Gaspersz, Vincent. 2012. All-In-One Talent Management. Bogor: Vinchristo Publication.

Hasibuan S P Malayu. 2010. Manajemen Sumber Daya Manusia. Edisi Revisi Cetakan ke Empat Belas. Jakarta: Bumi Aksara.

Moeheriono. 2010. Pengukuran Kinerja Berbasis Kompetensi. Bogor:Penerbit Ghalia Indonesia.

Moeherino. 2012. Pengukuran Kinerja Berbasis Kompetensi, Edisi Revisi, PT. Rajagrafindo Persada, Jakarta. p. 10

Nawawi, Hardari. 2006. "Evaluasi dan Manajemen Kinerja di Lingkungan Perusahaan dan Industri" Yogyakarta: Gadjah Mada University Press. Panji. 2009. Kompetensi Manajerial Kepala Sekolah dalam Meningkatkan Kinerja Guru. Tesis Karawang.

Prabu Mangkunegara, Anwar. 2011. Manajemen Sumber Daya Manusia Perusahaan. Bandung: PT. Remaja Rosdakarya.

Rivai, Velthzal dan Jauvani Sagala, Ella. 2009. Manajemen Sumber Daya Manusia Untuk Pembangunan. Jakarta : PT. Raja Grafindo Persada.

Sugiyono. 2012. "Metode Penelitian Kuantitatif, Kualitatif dan R\& D". Bandung : CV. Alfa Beta.

Susilowati. 2012. Pengaruh Kompetensi Pegawai dan Fasilitas Kerja Terhadap Kinerja Pegawai pada Badan Pengelolaan Lingkungan Hidup Kabupaten Karawang. Tesis, Program Pascasarjana Universitas Singaperbangsa Karawang 
Winardi. 2009. Manajemen Perilaku Organisasi. Edisi Revisi. Kencana Prenada Media Group. Jakarta. p. 61

https://skripsimahasiswa.blogspot.co.id/2014/03/metode-dan-tehnikpengumpulan-data.html

\section{Peraturan, Kebijakan dan Buku Pedoman}

1. 2004. undang-undang nomor 32 Tahun 2004 tentang Pemerintahan Daerah 